\title{
Prevalence of needle sticks injury and its associated factors among healthcare workers in Bahir Dar city Health Centres, Northwest Ethiopia
}

\author{
Wondimagegnehu Teju Legesse ${ }^{1}$, Worku Anemaw ${ }^{1}$, Teferi Mekonen ${ }^{1}$, Daniel Mekonnen ${ }^{2}$ \\ 1. Bahir Dar University, College of Medicine and Health Sciences, Department of Nursing \\ 2. Bahir Dar University, College of Medicine and Health Sciences, Department of Microbiology, \\ immunology and parasitology
}

doi: 10.3396/IJIC.v11i2.014.15

\begin{abstract}
It is important for HCWs to remember that over 20 pathogens have been reportedly transmitted from needle stick injuries. The most serious are the transmission of Hepatitis $C$ virus, Hepatitis B virus and Human immunodeficiency virus. World Health organization report showed that 16,000 HCV, 66,000 HBV \& 1000 HIV may have occurred worldwide. Two million needle stick injuries are reported in health care providers every year. This study was institution based cross-sectional study conducted in 10 Bahir Dar City public health centres from June to October 2014. 194 health care workers were selected using cluster followed by systematic random sampling technique. Data has been collected using pre tested self-administered questionnaire. The collected data was entered and analyzed by using SPSS statistical software version 20. Bi-variate logistic regression model was used to assess the association between dependent and independent variables and P-value less than 0.05 was considered statistically significant.
\end{abstract}

Among 194 study participants, 83 (42.8\%) participants showed history of needle stick injuries. Needle stick injuries were higher in outpatient departments and emergency unit, $59(30 \%)$ and delivery room $40(20.6 \%)$. The proportion of needle stick injuries were higher among health officers 16/30 (53.3\%). The major item cause for needle stick injuries were syringe with needle, 55/83 (66\%) and the most injured body part were fingers 58/83 (70.7\%). In conclusion, significant proportion of health care workers experienced needle sticks injuries. Therefore, ongoing training and supervision should be given to curb the situation in the study area.

Keywords: Health personnel; Needlestick injuries and epidemiology

\section{Corresponding Author}

Wondimagegnehu Teju Legesse

Bahir Dar University, College of Medicine and Health Sciences, Department of Nursing

Tel: +251-918-08-89-02

Email: wendim2006@gmail.com, 


\section{Introduction}

Needle stick injuries (NSIs) are wounds that occur when a needle or sharp instrument accidentally punctures the skin. ${ }^{1,2}$ With the introduction of blood or other potentially infectious material into the body, healthcare workers (HCW) are at risk of occupational acquisition of blood borne pathogens such as Hepatitis B viruses (HBV), Hepatitis C Virus (HCV), Human Immunodeficiency Virus (HIV) and other disease. The average risk of HIV transmission to HCW after exposure to HIV infected blood has been estimated as 3 in 1000. Seroconversion after a single needle stick exposure to an HBV-infected patient is estimated to be $6-30 \% .{ }^{3,4}$ It is important for HCWs to remember that over 20 pathogens have been reportedly transmitted from NSIs. ${ }^{5}$ The most serious are the transmission of HCV, HBV and HIV. ${ }^{6}$

Factors that determine a HCW's risk of infection include the frequency of needle stick incidents, the pathogen involved, the immune status of the worker, the severity of the NSI and the availability and use of appropriate post-exposure prophylaxis (PEP). ${ }^{\text {? }}$

The Centres for Disease Control and Prevention (CDC) estimates that about 385,000 sharps-related injuries occur annually among HCW in hospitals. Most reported sharps injuries involve nursing staff, laboratory staff, physicians, housekeepers, and other HCW. ${ }^{8}$ World Health Organization report showed that 16,000 HCV, 66,000 HBV \& 1000 HIV may have occurred worldwide. ${ }^{9}$ The annual estimated proportion of HCW exposed to blood born pathogen globally were $2.6 \%$ for HCV, $5.9 \%$ for HBV, and $0.5 \%$ for HIV. ${ }^{9}$

Numerous modifiable and non-modifiable factors place HCWs at risk of NSIs. The most common reasons are two handed recapping, and the unsafe collection and disposal of sharps waste. ${ }^{10}$ Two millions NSI are reported in health care providers every year. ${ }^{11}$ But these are only the reported cases and about $40-70 \%$ cases of NSI are unreported in developing countries. ${ }^{11}$

The study conducted in USA in 2002, shows that 57 HCW seroconvert to HIV following occupational exposure; of these, 26 have developed AIDS. ${ }^{12}$ Available statistics underestimate the severity of the NSIs problem in the study area because many HCWs do not report their injuries. Therefore, it is not known how serious the problem is or how well prevention programme will work. Based on this background, this study aimed to assess the prevalence of NSI and its associated factors among HCWs in Bahir Dar city public health centres, North western Ethiopia.

\section{Methods}

\section{Study Design, Period and Area}

The study was institution based cross-sectional study, conducted between June and October 2014 in public health centres in Bahir Dar city administration, northwest Ethiopia. The study was carried out in ten public health centres (Abaymado health centre $(\mathrm{HC})$, Shumabo HC, Han HC, Bahirdar HC, Ginbot Haya $\mathrm{HC}$, Shembet HC, Meshenti HC, Zegie HC, Zenzelema $\mathrm{HC}$ and Tiseabay HC).

\section{Source and study population}

The source populations include all health professionals working in the Bahir Dar city administrations. The study population has been those HCWs working in the ten public health centres and participated in this study.

\section{Sample Size and sampling technique}

In this study, $194 \mathrm{HCW}$ were selected using cluster followed by systematic random sampling technique.

\section{Data collection and Data Quality Assurance}

Datahasbeencollectedusingpretested selfadministered structured questionnaire. The questionnaire included questions on Socio-demographic characteristics and NSI. The data collectors trained on how to carry out the data collection and approach to the participants. Furthermore, the data has been checked daily for its completeness by the supervisors.

\section{Data Analysis}

The collected data was entered and analyzed by using SPSS statistical software version 20 (IBM Corp. Released 2011. IBM SPSS Statistics for Windows, Version 20.0. Armonk, NY: IBM Corp.). Frequency, percentage and mean were used to describe the participants with relevant variables using tables. Bi-variate logistic regression model has been used to assess the association between dependent and independent variables and P-value less than 0.05 considered statistically significant. 


\section{Ethical considerations}

Ethical clearance was obtained from the ethical committee of Bahir Dar University. Support and permission was secured from Bahir Dar city administrative health bureau and all health centres before data collection. Informed consent was obtained from study participants during data collection. The study participants were informed about the purpose of the study and the importance of their participation in the study and that they could stop at any time during data collection. Confidentiality has been maintained and the information collected has been used only for the purpose of this research.

\section{Results}

Socio demographic characteristics of the study participants

A total of 194 health professionals participated, 56 $(28.9 \%)$ and $138(71.1 \%)$ were male and female respectively. The mean age of participants was 29.9 years old, ranging from $21-54$. The majority $(95.4 \%)$ were orthodox Christian by religion, and nearly two third $(69.1 \%)$ were diploma holders by qualification. The majority of participants, 107 (55.2\%), were clinical nurses and $74.2 \%$ were married. Ninety five $(49 \%)$ participants had less than five years of work experience (Table I).

Table I. Socio demographic and work characteristics of the study participants Bahir Dar, North West Ethiopia, 2014

\begin{tabular}{|c|c|c|c|}
\hline Variable & Category & Frequency (n) & Percent (\%) \\
\hline \multirow[t]{2}{*}{ Sex } & Male & 56 & 28.9 \\
\hline & Female & 138 & 71.1 \\
\hline \multirow[t]{3}{*}{ Age (years) } & $\underline{20-29}$ & 116 & 59.8 \\
\hline & $\underline{30-49}$ & 75 & 38.7 \\
\hline & $>50$ & 3 & 1.5 \\
\hline \multirow[t]{4}{*}{ Marital status } & Married & 144 & 74.2 \\
\hline & $\underline{\text { Single }}$ & 49 & 25.3 \\
\hline & Divorced & 1 & .5 \\
\hline & Widow & 0 & 0 \\
\hline \multirow[t]{4}{*}{ Religion } & Orthodox & 185 & 95.4 \\
\hline & Muslim & 6 & 3.1 \\
\hline & Protestant & 2 & 1.0 \\
\hline & Other & 1 & .5 \\
\hline \multirow[t]{4}{*}{ Ethnicity } & Amhara & 191 & 98.5 \\
\hline & $\underline{\text { Tigre }}$ & 2 & 1.0 \\
\hline & Oromo & 1 & .5 \\
\hline & Other & 0 & 0 \\
\hline \multirow[t]{4}{*}{ Education level } & $\underline{\text { Diploma }}$ & 134 & 69.1 \\
\hline & BSc. & 58 & 29.9 \\
\hline & $2^{\text {nd }}$ degree & 1 & 0.5 \\
\hline & Others & 1 & 0.5 \\
\hline \multirow[t]{4}{*}{ Job category } & Nurse & 107 & 55.2 \\
\hline & Midwife & 32 & 16.5 \\
\hline & Health officer & 30 & 15.5 \\
\hline & Laboratory Technicians & 25 & 12.9 \\
\hline
\end{tabular}




\begin{tabular}{|c|c|c|c|}
\hline \multirow[t]{6}{*}{ Working area/Department } & OPD and emergency & 59 & 30.4 \\
\hline & Laboratory & 24 & 12.4 \\
\hline & Injection and dressing room & 18 & 9.3 \\
\hline & $\underline{\text { Delivery room }}$ & 40 & 20.6 \\
\hline & Under 5 & 21 & 10.8 \\
\hline & Others & 31 & 16.0 \\
\hline \multirow[t]{4}{*}{ Years in clinical practice } & $<5$ & 95 & 49 \\
\hline & $6-10$ & 66 & 34 \\
\hline & $11-20$ & 25 & 12.9 \\
\hline & $21-35$ & 8 & 4.1 \\
\hline
\end{tabular}

(Total number of participants $=194)$

\section{Prevalence of NSI}

Among 194 study participants, 83 (42.8\%) participants showed history of NSI in the preceding year. NSIs was higher in OPD and emergency unit, $59(30 \%)$, and delivery room $40(20.6 \%)$ than other working area (Table II). The proportion of NSI was higher among health officers $16 / 30(53.3 \%)$, followed by midwifery nurses $15 / 32(46.8 \%)$. The prevalence among nurse professionals was $43 / 107$ (40.1\%). The major item causing NSIs was syringe with needle, 55/83 (66\%), and the most injured body part were fingers $58 / 83$ (70.7\%) (Table II).

Table II. Prevalence of NSI among HCW and by socio demographic and work related factors, Bahir Dar, North West Ethiopia, 2014

\begin{tabular}{|c|c|c|c|}
\hline Variables & Descriptive & Frequency $(\mathrm{n}=)$ & Percent $(\%)$ \\
\hline \multirow[t]{2}{*}{ History of NSIs } & YES & 83 & 42.8 \\
\hline & $\mathrm{NO}$ & 111 & 52.7 \\
\hline \multirow[t]{3}{*}{ Age (years) } & $\underline{20-29}$ & 49 & 59.03 \\
\hline & $\underline{30-49}$ & 32 & 38.55 \\
\hline & $>50$ & 2 & 2.4 \\
\hline \multirow[t]{2}{*}{ Sex } & Male & 20 & 24 \\
\hline & Female & 63 & 76 \\
\hline \multirow[t]{4}{*}{ Job category } & Nurse & 43 & 51.8 \\
\hline & Midwife & 15 & 18.07 \\
\hline & Health officer & 16 & 19.28 \\
\hline & Laboratory Technician & 9 & 10.84 \\
\hline \multirow[t]{6}{*}{ Current working area } & OPD and emergency room & 26 & 31.32 \\
\hline & $\underline{\text { Laboratory }}$ & 9 & 10.84 \\
\hline & Injection and dressing room & 9 & 10.84 \\
\hline & Delivery room & 18 & 21.68 \\
\hline & Under 5 & 9 & 10.84 \\
\hline & Others & 12 & 14.45 \\
\hline \multirow[t]{4}{*}{ Years in clinical practice } & $\leq 5$ & 39 & 46.98 \\
\hline & $6-10$ & 29 & 34.94 \\
\hline & $11-20$ & 12 & 14.45 \\
\hline & $21-35$ & 3 & 3.6 \\
\hline
\end{tabular}




\section{Associated factors for NSI}

In this study we tried to assess the possible associated factors (sex, age, educational status, professional category, work area, clinical service year and training on occupational safety, universal precaution and recapping practice) for NSI. According to our findings, the prevalence of NSI was higher among female HCW than male but there was not statistical significant difference; $\mathrm{P}=0.205, \mathrm{OR}(95 \% \mathrm{Cl})=0.66(0.35-1.256)$. Moreover, proportion of NSI was also higher among health officers $(\mathrm{HO})$ followed by Midwifery nurses followed by nurse HCW but still failed to get significant difference on the prevalence of NSI by professional category, $\mathrm{P}=0.503$ (Table III).

Table III. Bi-variate analysis showing the association NSI with socio-demographic, work and training related factors, Bahir Dar, North West Ethiopia, 2014

\begin{tabular}{|c|c|c|c|c|c|c|c|}
\hline \multirow[b]{3}{*}{ Variables } & \multirow[b]{3}{*}{ Descriptive } & \multicolumn{6}{|c|}{ NSI } \\
\hline & & \multicolumn{3}{|c|}{ No } & \multirow{2}{*}{$\begin{array}{r}\text { Yes } \\
\% \\
\end{array}$} & \multirow[b]{2}{*}{ COR $(95 \% \mathrm{Cl})$} & \multirow[b]{2}{*}{ P-value } \\
\hline & & $\mathrm{N}$ & $\%$ & $\mathbf{N}$ & & & \\
\hline \multirow[t]{2}{*}{ Sex } & Male & 36 & 64.2 & 20 & 35.8 & $0.66(0.35-1.25)$ & 0.205 \\
\hline & Female & 75 & 54.3 & 63 & 45.7 & 1 & \\
\hline \multirow[t]{3}{*}{ Age } & $20-29$ & 67 & 57.8 & 49 & 42.2 & 1 & \multirow{3}{*}{0.70} \\
\hline & $30-49$ & 43 & 57.4 & 32 & 42.6 & $0.10(0.65-1.8)$ & \\
\hline & $>50$ & 1 & 33.3 & 2 & 66.6 & $2.73(0.24-31.01)$ & \\
\hline \multirow[t]{4}{*}{ Job category } & Nurse & 64 & 59.8 & 43 & 40.1 & 1 & \multirow{4}{*}{0.503} \\
\hline & Midwifery & 17 & 53.1 & 15 & 46.8 & $1.3(0.59-2.9)$ & \\
\hline & $\underline{\mathrm{HO}}$ & 14 & 46.6 & 16 & 53.3 & $1.7(0.75-3.84)$ & \\
\hline & Lab .Tec & 16 & 64 & 9 & 36 & $0.8(0.34-2.0)$ & \\
\hline \multirow[t]{4}{*}{ Work experience } & $<5$ & 56 & 59 & 39 & 41 & 1 & \multirow{4}{*}{0.914} \\
\hline & $\underline{6-10}$ & 37 & 56 & 29 & 44 & $1.25(0.6-2.1)$ & \\
\hline & $\underline{11-20}$ & 13 & 52 & 12 & 48 & $1.32(0.5-3.2)$ & \\
\hline & $21-35$ & 5 & 62.5 & 3 & 37.5 & $0.86(0.19-3.81)$ & \\
\hline \multirow[t]{6}{*}{$\begin{array}{l}\text { Current working } \\
\text { area }\end{array}$} & $\begin{array}{l}\text { OPD and } \\
\text { emergency room }\end{array}$ & 33 & 56 & 26 & 44 & 1 & \multirow{6}{*}{0.89} \\
\hline & Laboratory & 16 & 64 & 9 & 36 & $0.91(0.33-2.49)$ & \\
\hline & $\begin{array}{l}\text { Injection \& } \\
\text { dressing room }\end{array}$ & 9 & 50 & 9 & 50 & $0.66(0.2-1.66)$ & \\
\hline & $\underline{\text { Delivery room }}$ & 22 & 61 & 18 & 39 & $1(0.44-2.23)$ & \\
\hline & Under 5 & 12 & 54.5 & 9 & 45.5 & $1.22(0.42-3.5)$ & \\
\hline & Others & 19 & 61.2 & 12 & 38.8 & $0.77(0.13-1.86)$ & \\
\hline \multirow{2}{*}{$\begin{array}{l}\text { Participate training } \\
\text { on occupational } \\
\text { safety }\end{array}$} & YES & 42 & 53.8 & 36 & 46.2 & 1 & \multirow[t]{2}{*}{0.43} \\
\hline & $\mathrm{NO}$ & 69 & 59.4 & 47 & 40.6 & $0.79(0.4-1.4)$ & \\
\hline $\begin{array}{l}\text { Participate Training } \\
\text { on }\end{array}$ & YES & 20 & 51.2 & 19 & 48.8 & 1 & 0.4 \\
\hline $\begin{array}{l}\text { Universal } \\
\text { Precaution } \\
\end{array}$ & NO & 91 & 59 & 63 & 41 & $0.74(0.36-1.49)$ & \\
\hline \multirow[t]{4}{*}{ Recapping practice } & Never recap & 60 & 58.2 & 43 & 41.8 & 1 & \multirow{4}{*}{0.54} \\
\hline & Sometimes recap & 21 & 33.8 & 41 & 66.2 & $0.9(0.42-2.0)$ & \\
\hline & $\underline{\text { Little times recap }}$ & 17 & 47.2 & 19 & 52.8 & $1.56(0.72-3.43)$ & \\
\hline & Always recap & 13 & 65 & 7 & 35 & $0.75(0.27-2.04)$ & \\
\hline
\end{tabular}




\section{Discussion}

This study was an important addition to the existing literature. Like that of different studies our finding confirmed that NSI was a major work associated health risk in our country especially in the study area. Among the $194 \mathrm{HCW}$ that participated in this study, 83 (42.8\%) had experienced some type of NSI during service delivery. This result showed that large proportions of HCW in the study area were exposed to infectious and deadly blood borne pathogens like HBV, $\mathrm{HCV}$ and HIV. According to the participants report, 47/83 (56.6\%) and 63/83 (75.9\%) participants did not have any occupational safety and universal precaution training respectively. Moreover, 61/83 (73.5\%) and $57 / 83(68.67 \%)$ did not take any antiretroviral (ARV) PEP for HIV and did not report their injury to their supervisor for immediate medical attention (Table II and III) despite there is ARV PEP and line of reporting system with assigned supervisor. ${ }^{13,14}$ All these figures showed that infection prevention activities were neglected in Bahir Dar city administrative healthcare facilities. The healthcare workforce, 35 million people world wide, represents $12 \%$ of the working population. The occupational health of this significant group has long been neglected, both organizationally and by governments. ${ }^{15}$

According to this study, HCW who have recapping practice have lower risk of NSI than HCW who have no recapping history. This is in contrast with current literature. The possible reasons might be their awareness for the association of recapping and NSI might be high, those not recapping were more observant to following instructions including reporting, or that their sharps injury occurred in other situations.

When we compared our finding of NSI prevalence with studies done in Pakistan 67\%, ${ }^{16}$ Sub-Saharan Africa $57 \%,{ }^{12}$ and Ethiopia $66 \%,{ }^{17}$ the prevalence of NSI in the present study was lower. The reason why our study is lower than the other studies might be the difference in the study population, sample size and time frame. In our cases we included all HCW like nurses, health officers, midwifery nurses and laboratory technicians but studies in Pakistan used only nursing professionals, Uganda only nurses and midwives, Ethiopia only among nurses who were working at injection room. On the other hand our finding was higher than studies done in Nigeria 34\%, ${ }^{18}$ in Felege Hiwot Referal Hospital (FHRH) in Ethiopia 31\% ${ }^{19}$ and Assam 52/220 $(27.4 \%) .{ }^{20}$ The reason behind these difference might be difference in level of education, training and the infection prevention programme of the health facility that unlike our, the Nigerian and FHRH studies were done in teaching hospitals where high level, skilled and experienced professionals were found. Moreover, as compared to health centres, hospitals, especially teaching hospitals, might have better infection prevention activities.

In our study, the prevalence of NSI was higher among female, at age range of 20-29 years of old, HOs, work experience of less than 5 years, working at injection and dressing room but not statistically significance in all cases $(P>0.05)$. As it can be seen from the table III, the $95 \% \mathrm{Cl}$ was so wide indicating that the sample size was small and was not good enough to strongly conclude that there were no associations in this study. Even though there were methodology and study site differences, our study was in line with Pakistan, Ugandan and Ethiopian studies. A study in Pakistan, and Uganda showed that lack of training was the main factors leading to needle stick injuries, ${ }^{10,12}$ working for more than 40 hour per week, recapping needles and not using gloves when handling needles were associated factors. ${ }^{12} \mathrm{~A}$ recent study in $\mathrm{FHRH}$ also identified suboptimal practices and behaviours that put them at risk to the injury. ${ }^{19}$

\section{Conclusions and Recommendations}

The findings of this study indicated that NSI were common among health care workers. Health facilities should put a policy, a standardized written protocol and line of communication for management of occupational exposures. Moreover, on job training should be given to HCW. Further research is needed to determine the actual incidence of NSI and sharp injury exposure, and the type of disease they would acquire.

\section{Acknowledgements}

Our first deepest gratitude would be to Bahir Dar University College of Medicine and Health Sciences allowing us to conduct this study. We would like to acknowledge Bahir Dar City Administration Health office and health centres for their support. We also like to thanks all the study participants. 


\section{References}

1. Canadian Centre for Occupational Health and Safety (CCOHS). Needle- Stick injuries. OSHA. Needle sticks injuries 2005.

2. Newsom DH, Kiwanuka JP. Needle-Stick Injuries. Bandolier Extra: Evidence based Healthcare. 2003.

3. Gerberding JL. Incidence and prevalence of human immunodeficiency virus, hepatitis B virus, hepatitis C virus, and cytomegalovirus among health care personnel at risk for blood exposure: Final report from a longitudinal study. I Infect Dis 1994; 170: 1410-1417. http://dx.doi.org/10.1093/ infdis/170.6.1410

4. Tokars JI, Marcus R, Culver DH, et al. Surveillance of HIV infection and zidovudine use among health care workers after occupational exposure to HIV-infected blood. Ann Intern Med 1993; 118: 913-919. http://dx.doi.org/10.7326/0003-4819118-12-199306150-00001

5. USA Department of Labour. Occupational safety and health administration. How to Prevent Needle stick Injuries: Answers to Some Important Questions 2005. Available on URL www.osha.gov/index.html

6. WGabriel Y. Assessment of the safety injection and related medical practices in health institution at Sidama zone, SNNPRS, Ethiopian public health association (EPHA), Extracts of MPH theses works by EPHA sponsored graduate students in public health, September 2004; pp53-56.

7. Cardo DM, Culver DH, Ciesielski CA, et al. A case-control study of HIV seroconversion in healthcare workers after percutaneous exposure. N Engl J Med 1997; 337: 1485-1490. http://dx.doi.org/10.1056/NEJM199711203372101

8. Smith DR, Smyth W, Leggat PA, Wang RS. Needle stick and sharps injuries among nurses in a tropical Australian hospital. Int / Nurs Practice 2006; 12: 71-77. http://dx.doi.org/10.1111/ j.1440-172X.2006.00553.x

9. Pruss-Ustun A, Rapiti E, Hutin Y. Sharps injuries: Global burden of disease from sharps injuries to health-care workers. Geneva, World Health Organization, 2003 (WHO Environmental Burden of Disease Series, No.3).

10. Zafar A, Habib F, Hadwani $R$, et al. Impact of infection control activities on the rate of needle stick injuries at a tertiary care hospital of Pakistan over a period of six years: an observational study. BMC Infect Dis 2009; 9: 78. http://dx.doi. org/10.1186/1471-2334-9-78
11. Against all reason: misuse and overuse of injections /Misuse/ en/index.html (Accessed on 22 March 2010).

12. Nsubuga FM, Jaakkola MS. Needle stick injuries among nurses in sub-Saharan Africa. Trop Med Int Health 2005; 10(8): 773 781. http://dx.doi.org/10.1111/j.1365-3156.2005.01453.x

13. Mathewos B, Birhan W, Kinfe S, et al. Assessment of knowledge, attitude and practice towards post exposure prophylaxis for HIV among health care workers in Gondar, North West Ethiopia. BMC Public Health 2013; 13: 508. http:// dx.doi.org/10.1186/1471-2458-13-508

14. Tebeje B, Hailu Ch. Assessment of HIV post-exposure prophylaxis use among health workers of governmental health institutions in Jimma zone, Oromiya Region, Southwest Ethiopia. Ethiop / Health Sci 2010; 20(1): 55-64.

15. Wilburn SQ, Eijkemans G. Preventing needle stick injuries among healthcare workers: A WHO-ICN collaboration. Int J Occup Environ Health 2004; 10: 451-456. http://dx.doi. org/10.1179/oeh.2004.10.4.451

16. Habib H, Ahmed Khan E, Aziz A. Prevalence and Factors Associated with Needle Stick Injuries among Registered Nurses in Public Sector Tertiary Care Hospitals of Pakistan. Int I of Collaborative Res on Intern Med \& Public Health 2011; 3(2): 124-130

17. Yemane B, Millogo J. Report of Injection Safety Survey in Ethiopia. Geneva, Switzerland, 2000: pp: 22

18. Adegboye AA, Moss GB, Soyinka F, Kreiss JK. The epidemiology of needle stick and sharp instrument accidents in a Nigerian hospital, Nigeria. Infect Control Hosp Epidemiol 1994, 15(1): 27-31. http://dx.doi.org/10.2307/30148382

19. Walle L, Abebe E, Tsegaye M, Franco H, Birhanu D, Azage M. Factors associated with needle stick and sharp injuries, among healthcare workers in Felege Hiwot Referral Hospital, Bahir Dar, Northwest Ethiopia: facility based cross-sectional survey. Int J Infect Control 2013; 9(4).

20. Gupta E, Katiyar V. Study on Needle stick injuries among nurses of atertiary care hospital of Assam. Indian J of Appl Res 2013; 3(7): 472-473. http://dx.doi.org/10.15373/2249555X/ JULY2013/144 